\title{
Red Flag Effectiveness in Public Sector Audit Using Fraud Pentagon Theory
}

\author{
Magnaz Lestira Oktaroza, Pupung Purnamasari", Rudy Hartanto, Annisa Nadiyah Rahmani \\ Department of Accounting, Faculty of Economics and Business, Universitas Islam Bandung, Indonesia
}

Received October 22, 2021; Revised December 13, 2021; Accepted January 22, 2022

\section{Cite This Paper in the following Citation Styles}

(a): [1] Magnaz Lestira Oktaroza, Pupung Purnamasari, Rudy Hartanto, Annisa Nadiyah Rahmani, "Red Flag Effectiveness in Public Sector Audit Using Fraud Pentagon Theory," Universal Journal of Accounting and Finance, Vol. 10, No. 1, pp. 338 - 347, 2022. DOI: 10.13189/ujaf.2022.100134.

(b): Magnaz Lestira Oktaroza, Pupung Purnamasari, Rudy Hartanto, Annisa Nadiyah Rahmani (2022). Red Flag Effectiveness in Public Sector Audit Using Fraud Pentagon Theory. Universal Journal of Accounting and Finance, 10(1), 338 - 347. DOI: 10.13189/ujaf.2022.100134.

Copyright $\mathrm{C} 2022$ by authors, all rights reserved. Authors agree that this article remains permanently open access under the terms of the Creative Commons Attribution License 4.0 International License

\begin{abstract}
Auditors in carrying out fraud detection do not always get a bright spot, because the perpetrators have many ways to commit fraud and various underlying motivations. This reason strengthens government auditors, and it is important to understand or recognize indicators or red flags in determining fraud risk assessments. The aim of this article is to gather empirical evidence on how public sector auditors perceive fraud detection. Partial Least Square analysis is the method used. The number of samples in this study was 96 government auditors consisting of 48 BPKP auditors and 48 BPK auditors. The findings demonstrate that gender, duration of employment, and education and training of auditors at BPKB have an impact on the effectiveness of red flags, whereas auditors at BPK have a different impact, with job position, education, and training having an impact on red flag effectiveness. The results of this study give attention to BPKP and BPK to provide opportunities for auditors to participate in continuing education and participate in training that supports auditors in carrying out their work, especially related to training in the use of IT to detect fraud. The perception theory can explain the usefulness of red flags in detecting fraud, according to the findings of this study. This means that in determining the ability to use red flags, it is influenced by individual characteristics (gender, position, length of employment), and the capacity of auditors (education and training).
\end{abstract}

Keywords External Auditor, Fraud Pentagon, Government Auditor, Internal Auditor, Red Flags Effectiveness

\section{Introduction}

The manifestation of transparency and accountability in financial statements, both in the public and private sectors, is conducted by the audit of finance by independent bodies. The role of public sector auditors is critical in promoting the credibility, equality, and acceptable behavior of public sector top officials, as well as reducing the risk of corruption [1]. The audit of public sector editors in Indonesia is carried out by the Audit Board of the Republic of Indonesia (BPK) as external auditors, as well as the National Development and Financial Supervisory Agency (BPKP).

If BPK's auditors discover an initial fraud signal, also known as red flags, they can take action by proposing an audit with a specific objective in the form of an investigative audit conducted by BPKP [2]. The red flag approach is a technique for detecting fraud that is endorsed by the majority of audits [3]. Internal and external auditors both have a role in detecting fraud using red flags. Internal auditors employ red flags to prevent, discover, investigate, and report fraud, whereas external auditors use red flags to make decisions about delivering financial report opinions [4].

Detecting fraud for BPK and BPKP auditors is a difficult assignment that necessitates not only a thorough understanding of the characteristics of fraud, but also an understanding of how the fraudster commits fraud. Auditors don't always get a clear clue when it comes to detecting fraud because fraudsters have a variety of methods and objectives for committing it. As a result, it is critical for auditors to comprehend and recognize its 
indicators or red flags when estimating the risk of fraud [5]. Red flags are important in early fraud detection, according to a number of experts and fraud-audit auditors [6].

The effectiveness of red flags can be influenced by auditors' experience and audit training [7], as well as their length of service or employment [5]. Gender differences in audit judgment accuracy and audit job difficulty have been observed in the past $[8,9]$, but contended that gender, auditor experience, and length of employment have no significant impacts on auditor detection [8].

Many factors influence the identification of fraud employing red flags, according to empirical research $[10,11,12,13]$. Studies on the effectiveness of red flags in the public sector are still limited to comparing internal and external auditors' perceptions [7,14,4,15], as well as the importance of red flags in detecting fraud $[15,16]$. The approach to testing the effectiveness of red flags in both public and private sectors remains limited to the usage of the fraud triangle theory model $[7,4,17,6]$. Meanwhile, the rise in deception incidents as a result of changes in culture and organizational technology has prompted the development of theories of corrupt behavior, including the fraud triangle hypothesis [18], which prepared the way for the fraud pentagon theory [19].

This research stands out for two reasons: To begin, this study uses a red flag strategy based on the fraud pentagon theory, which has never been applied in previous studies. Second, it relies on the perceptions of government auditors, both external and internal, at the governmental level to identify red flags.

\section{Theoretical Background and Literature Review}

\subsection{Perception Theory}

Perception theory assumes that an action towards others is influenced by the social environment and is not influenced by others and is not influenced by the social environment which is not influenced own. Perception theory also assumes that people believe they interpret their behavior that is not hidden in the same way, as they interpret the behavior of others. Self-perception theory is considered one of the most influential theories, which explains how self-knowledge is obtained [20].

\subsection{Fraud Pentagon Theory}

Fraud is an act that encompasses evil thoughts, cheating, and betrayal behavior, in which the action is done to fool others and for personal interests that result in other individuals' loss [21]. There are various perspectives that auditors can take to prevent the possibility of fraud, one of which is fraud pentagon theory, which was revealed in 2011 by Horwarth [19]. This theory consists of five indicators namely pressure, opportunity, rationalization, capability and arrogance. Fraud pentagon theory is a development of the previously stated theory by Cressey [18], which is famous for its fraud triangle theory. This theory, then, was conveyed by Wolfe and Hermanson [22], as fraud diamond theory. This fraud pentagon theory is a large-scale fraud involving the CEO or CFO, due to the financial statement manipulation carried out by internal officials of a company. In addition, authorities have access to financial statement information that can be obtained by internal officials.

\subsection{Red Flags Effectiveness}

Red flags are auditor activities in detecting fraud through indicators or signs of fraud [23]. However, there are various reasons that ultimately the auditor ignores these signs, such as maintaining the company's reputation, market potential, and employee motivation. Eventually, the auditor may intentionally not disclose the indicators of fraud in the audit report, or not discuss it with the company's management [24].

Each red flag in fact has a different level of effectiveness in detecting fraud. The effectiveness of red flags can occur because of differences in perceptions $[12,25]$, personal characteristics that judge [26], incentives [27], or differences in activities and responsibilities. related to work [16]. Even individuals who are in the same profession, namely internal auditors and external auditors, have different perceptions of the effectiveness of red flags.

\subsection{Gender and Red Flag Effectiveness}

The term "gender" refers more to social concepts rather than biological. Biologically, sex differences are natural in essence while the concept of gender is a relative difference in a number of inherent characters and behaviors that are socially, culturally, politically, theologically and economically constructed by men or women [28].

Moyes and Baker [7] study inferred that female auditors have a greater tendency to use red flags in detecting inclination compared to male auditors. This research results are supported by Ittonen [29] who found that female auditors have much higher audit fees compared to men because of women's persistence, professional skepticism, and a higher level of preparation compared to men. Therefore, more audit investments will be generated by female auditors. From previous theory and research which show the same concept that women have a greater tendency to use red flags in an effort to detect fraud, the first hypothesis is:

$$
\begin{aligned}
& \text { H1: Gender characteristics influence red flag } \\
& \text { effectiveness }
\end{aligned}
$$

\subsection{Job Position and Red Flag Effectiveness}

Job position in this study is seen based on position, i.e., structural, functional auditor and general. Moyes and 
Baker [7] categorize job positions that consist of partners, executive directors, senior managers, senior executives, and associates. According to IAASB [30], the Partner is also responsible for the overall quality of each audit engagement and also ensures that the work of the Audit Manager, Senior Audit and Audit Staff runs according to professional standards and also complies with applicable legal requirements. A Partner is also required to conduct a review of the subordinate's work by looking at the procedures of which are carried out accordingly, team discussions, and reviews of audited financial statements and audit reports. Partner position is the most difficult level in the work of an auditor because of his great responsibilities. Thus, he is demanded to have adequate knowledge and experience. Auditors whose higher positions will be more experienced in making better judgment in carrying out their professional duties. So, auditors with higher positions tend to have the potential to use red flags in detecting fraud than auditors who are still in low positions. Hence, the second hypothesis in this study is as follows:

H2: Job position characteristics influence red flag effectiveness.

\subsection{Years of Service and Red Flag Effectiveness}

The years of service is the time a person spends during his employment in certain specific agencies. For an auditor, the length of years in services by an auditor suggests that he is able to appropriately detect fraud $[5,14,31]$. The longer auditor's working tenure, the more auditors can understand work and tasks better [32] and more extensive knowledge in developing thinking skills compared to inexperienced auditors [33]. Research conducted by support the theory that shows the influence of the working period on an auditor's perception of the effectiveness of red flags [5]. Therefore, the third hypothesis in this study is as follows:

H3: Years of service characteristics influence red flag effectiveness.

\subsection{Education and Red Flag Effectiveness}

Educated auditors, for example master's degree holders, are more able to improve quality as they can be more aroused, asking critical questions, and collecting audit evidence to detect more errors in the presentation of financial statements compared to bachelor's degree holders' auditors. An auditor with postgraduate backgrounds can also have the capacity to influence the decision-making process. Therefore, auditors with higher education background can conduct red flags effectively [34]. A similar research also found that someone's educational level affected decision making paradigm [15,31]. To sum up, auditors who have higher education will have a wider paradigm and better decision-making in detecting red flags effectiveness. Hence, the fourth hypothesis in this study is as follows:

H4: Educational competency influences red flag effectiveness.

\subsection{Experiences and Red Flag Effectiveness}

For auditors to become experienced auditors, they must start their careers through seeking experience in the Public Accounting Firm (KAP) as an auditor staff. This is then followed by involving themselves in a team, in which they oversee the work of audit staff, namely senior auditors, auditor managers and partners. Following this, auditors who have long work tenure can be said to be experienced auditors because the longer period they spend at work as auditors will increase their knowledge in the auditing field. This is in line with several studies which show that the experience of an auditor can help him effectively detect fraud $[14,15,31,35,36]$. Considering this premise, the fifth hypothesis in this study is as follows:

H5: Experiences competency influences red flag effectiveness

\subsection{Training and Red Flag Effectiveness}

Training is a teaching process for new or existing employees with the aim of equipping employees with necessary basic skills needed in carrying out their work [37]. Training is one of the efforts used in improving the quality of human resources in the workforce. Both new and existing employees need to attend training because of the demands for the change of work affected by rapid changes in the work environment and company strategies.

Audit training for fraud covers discussion around the technique used by an auditor in detecting fraud. This can be conducted by analyzing deeper evidence in the form of a statement of testimony. Professional auditors are required to always attend adequate training. The more often auditors attend training on audit fraud, the more capable auditors can produce various explanations of audit findings that can reduce their professional skepticism. Conversely, auditors who frequently attend training will always question and critically evaluate and understand insight [38]. The results of previous studies [15,38] show that the results of fraud training can affect auditor perceptions of the effectiveness of red flags. Therefore, the sixth hypothesis in this study is as follows:

H6: Training competency characteristics influence red flag effectiveness

\section{Research Method}

\subsection{Population and Sample}

The sample in our study was auditors working in BPK and BPKP agencies. The reason for selecting auditors at the BPK and BPKP is because the auditors at these 
institutions are the auditors who most requently carry out investigative audits and are asked to calculate the alleged number of state financial losses in corruption cases. This study uses an analysis with a structured equation model (Structure Equation Model-SEM). Analysis of the data used Structural Equation Model (Structural Equation Model) with the alternative method of partial least squares (SEM-PLS).

\subsection{Measurement of the Variable and Data Analysis}

The instrument used to measure the construction of Forensic Auditor Perceptions is analyzed from the characteristics (gender, job position and years of service) and abilities (education, experience, training) [5,14,15,29]. Whereas the effectiveness of red flags consists of 5 dimensions of the pentagon fraud model, i.e., Opportunity, Pressure, Rationalization, Capability and Arrogance
$[4,19]$.

\section{Result and Discussion}

\subsection{Descriptive Statistics}

Table 1 described theoretical range, actual range, theoretical median, average actual, and standard deviation of research variables. From table 1 it can be seen that the BPKP and BPK auditors' perceptions of years of service, education, experience, and training have been positive . This was indicated by the actual average value which was greater than the theoretical median. These findings implied that to conduct a better audit, it would require an increase in work years of service, education, experience and training.

Table 1. Research Variable Description

\begin{tabular}{|c|c|c|c|c|c|}
\hline Sample & Theoretical Range & Actual Range & Theoretical Median & Average Actual & Standard Deviation \\
\hline \multicolumn{6}{|c|}{ Description of Auditors' Years of Service Perception } \\
\hline BPKP & $5-25$ & $17-24$ & 15 & 20,29 & 2,22 \\
\hline BPK & $5-25$ & $18-25$ & 15 & 22,50 & 2,86 \\
\hline \multicolumn{6}{|c|}{ Description of Auditors' Education Perceptions } \\
\hline ВРКP & $5-25$ & $14-24$ & 15 & 19,75 & 2,21 \\
\hline BPK & $5-25$ & $19-25$ & 15 & 22,88 & 2,23 \\
\hline \multicolumn{6}{|c|}{ Description of Auditors' Experience Perceptions } \\
\hline BPKP & $10-50$ & $31-49$ & 30 & 39,25 & 3,87 \\
\hline BPK & $10-50$ & $35-50$ & 30 & 41,21 & 3,82 \\
\hline \multicolumn{6}{|c|}{ Description of Auditors' Training Perceptions } \\
\hline BPKP & $4-20$ & $12-20$ & 12 & 15,83 & 1,76 \\
\hline BPK & $4-20$ & $16-20$ & 12 & 18,13 & 2,01 \\
\hline \multicolumn{6}{|c|}{ Description of Auditor Opportunities Responses } \\
\hline BPKP & $28-140$ & $37-136$ & 84 & 91,29 & 29,87 \\
\hline BPK & $28-140$ & $28-63$ & 84 & 37,88 & 14,47 \\
\hline \multicolumn{6}{|c|}{ Description of Auditor's Pressure Response } \\
\hline BPKP & $13-65$ & $35-59$ & 39 & 48,96 & 5,65 \\
\hline BPK & $13-65$ & $20-41$ & 39 & 29,00 & 8,84 \\
\hline \multicolumn{6}{|c|}{ Auditor's Description Rationalization } \\
\hline ВРКР & $15-75$ & $28-72$ & 45 & 52,96 & 13,39 \\
\hline BPK & $15-75$ & $18-33$ & 45 & 21,17 & 4,62 \\
\hline \multicolumn{6}{|c|}{ Description of Auditor Competence Responses } \\
\hline ВРКР & $6-30$ & $16-24$ & 18 & 21,29 & 2,42 \\
\hline BPK & $6-30$ & $16-24$ & 18 & 21,96 & 1,99 \\
\hline \multicolumn{6}{|c|}{ Description of Auditor Arrogance Responses } \\
\hline BPKP & $4-20$ & $4-19$ & 12 & 13,25 & 4,60 \\
\hline BPK & $4-20$ & $4-19$ & 12 & 12,75 & 4,22 \\
\hline \multicolumn{6}{|c|}{ Description of Auditor Responses About the Effectiveness of Red Flags } \\
\hline BPKP & $66-330$ & $138-299$ & 198 & 227,75 & 46,46 \\
\hline BPK & $66-330$ & $90-172$ & 198 & 122,75 & 25,97 \\
\hline
\end{tabular}


BPKP auditor's responses to the opportunity and pressure to commit fraud is still high, which can be seen from the actual average value that was greater than the theoretical median. Whereas the BPK auditor's responses to the opportunity and pressure to commit fraud has been already low, which was indicated by the actual average value that was smaller than the theoretical median. The high fraud responses at BPKP illustrated that there were still many opportunities that can be used to commit fraud in government agencies, whereas auditors at BPK believe that there was little opportunity of committing fraud in government agencies. The high pressure response at BPKP shows that there were still a lot of pressure to commit fraud in government agencies, whereas auditors at BPK believed that there was little pressure.

The competence responses in understanding and exploiting a situation in government agencies and arrogance seem to be still high both in BPKP and BPK. This was indicated by the actual average value that was greater than the theoretical median. This showed that auditors at BPKP and at BPK having the same opinions in that the competence to understand and exploit a situation and the arrogance of the apparatus in government agencies were still high.

BPKP auditors' responses about accounting rationalization were still frequent, which was indicated by the actual average value that was greater than the theoretical median. On the other hand, BPK auditors had different opinions that accounting rationalization was rare, which was shown by the actual average value that was smaller than the theoretical median. Hence, this data illustrated that auditors at BPKP believed that accounting rationalization still often occurs in government agencies, whereas auditors at BPK thought that accounting rationalization rarely occurs in government agencies.

BPKP auditor's response to effectiveness in anticipating fraud (red flags) has been high, which was demonstrated by the actual average value that was greater than the theoretical median. In contrast, BPK auditors have not been effective in anticipating fraud which was indicated by the actual average value that was smaller than the theoretical median. Whereas the characteristics related to gender and job position were presented in the following table 2:

Table 2. Gender and Position

\begin{tabular}{cccccc}
\hline \multirow{2}{*}{ No } & \multirow{2}{*}{$\begin{array}{c}\text { General } \\
\text { Characteristics }\end{array}$} & \multicolumn{2}{c}{ BPKP } & \multicolumn{2}{c}{ BPK } \\
\cline { 2 - 6 } & $\mathbf{N}$ & $\mathbf{\%}$ & $\mathbf{N}$ & $\mathbf{\%}$ \\
\hline 1 & Gender & & & & \\
& Male & 16 & $33,3 \%$ & 20 & $41,7 \%$ \\
2 & Female & 32 & $66,7 \%$ & 28 & $58,3 \%$ \\
& Job Position & & & & \\
& Team Leader & 44 & $91,7 \%$ & 36 & $75,0 \%$ \\
& Team Member & 4 & $8,3 \%$ & 12 & $25,0 \%$ \\
\hline
\end{tabular}

\subsection{Reliability and Validity Test}

There were 7 latent variables with a total of 11 manifest variables. Exogenous latent variables consisting of gender, job position, years of service, education, experience, and training were used as measured variables. Afterward, effectiveness of the red flag latent variable consisted of 5 manifest variables. According to Hair [39], indicators with factor weights less than 0.4 must be excluded from the measurement model, while composite reliability values between 0.70 to 0.90 are considered satisfactory.

The factor weights in table 4 illustrated that in the BPKP the five dimensions used to measure the latent variable effectiveness of the red flag (RF) have a loading factor greater than 0.4 , thus, were declared valid. The RF1,3 dimension (rationalization) had the biggest loading factor, which means that the rationalization dimension was the strongest in reflecting the effectiveness of the red flag latent variable. In contrast, the RF1,2 (pressure) dimension was the weakest in reflecting the effectiveness of the red flag latent variable. Furthermore, the results of the calculation of composite reliability and variance extracted for each latent variable.

The composite reliability and variance in table 3 extracted values of the six exogenous latent variables in BPKP were 1 because those were the measured variables. Additionally, the effectiveness of the red flags latent variable composite reliability had a value of 0.877 which was greater than 0.70 . These findings meant that the five dimensions that were used to measure the effectiveness of red flags latent variable already had adequate consistency.

In BPK, the composite reliability and variance extracted values of the six exogenous latent variables were 1 because those were the measured variables. Additionally, the effectiveness of the red flags latent variable composite reliability had a value of 0.944 which was greater than 0.70 . These findings meant that the three remaining dimensions that were used to measure the effectiveness of red flags latent variable already had consistency.

Table 3. CR and VE Measurement Model in BPKP and BPK

\begin{tabular}{ccccc}
\hline \multirow{2}{*}{ Variabel Laten } & \multicolumn{2}{c}{ BPKP } & \multicolumn{2}{c}{ BPK } \\
\cline { 2 - 5 } & CR & VE & CR & VE \\
\hline Gender (sex) & 1,00 & 1,00 & 1,00 & 1,00 \\
Job position (job) & 1,00 & 1,00 & 1,00 & 1,00 \\
$\begin{array}{c}\text { Competency } \\
\text { (comp) }\end{array}$ & 1,00 & 1,00 & 1,00 & 1,00 \\
Education (edu) & 1,00 & 1,00 & 1,00 & 1,00 \\
Experience (exp) & 1,00 & 1,00 & 1,00 & 1,00 \\
Training (tra) & 1,00 & 1,00 & 1,00 & 1,00 \\
$\begin{array}{c}\text { Effectiveness of } \\
\text { the red flag (RF) }\end{array}$ & 0,877 & 0,592 & 0,944 & 0,849 \\
\hline
\end{tabular}


Table 4. Convergent Validity

\begin{tabular}{|c|c|c|c|c|c|c|c|}
\hline Variable Construct & $\begin{array}{l}\text { Effectiveness of } \\
\text { the red flags }\end{array}$ & Gender & $\begin{array}{c}\text { Job } \\
\text { Position }\end{array}$ & Competency & Education & Experience & Training \\
\hline \multicolumn{8}{|l|}{ Model BPKP } \\
\hline$(\mathrm{RF} 1,1)$ & 0.783 & & & & & & \\
\hline$(\mathrm{RF} 1,2)$ & 0.625 & & & & & & \\
\hline (RF 1,3) & 0.887 & & & & & & \\
\hline$(\mathrm{RF} 1,4)$ & 0.692 & & & & & & \\
\hline (RF 1,5) & 0.832 & & & & & & \\
\hline $\operatorname{sex}$ & & 1.000 & & & & & \\
\hline Job & & & 1.000 & & & & \\
\hline Com & & & & 1.000 & & & \\
\hline Edu & & & & & 1.000 & & \\
\hline Exp & & & & & & 1.000 & \\
\hline Tra & & & & & & & 1.000 \\
\hline \multicolumn{8}{|l|}{ Model BPK } \\
\hline (RF 1,1) & 0.916 & & & & & & \\
\hline$(\mathrm{RF} 1,2)$ & 0.937 & & & & & & \\
\hline$(\mathrm{RF} 1,3)$ & 0.911 & & & & & & \\
\hline$(\mathrm{RF} 1,4)$ & 0.320 & & & & & & \\
\hline$(\mathrm{RF} 1,5)$ & 0.301 & & & & & & \\
\hline $\operatorname{sex}$ & & 1.000 & & & & & \\
\hline Job & & & 1.000 & & & & \\
\hline Com & & & & 1.000 & & & \\
\hline Edu & & & & & 1.000 & & \\
\hline Exp & & & & & & 1.000 & \\
\hline Tra & & & & & & & 1.000 \\
\hline
\end{tabular}

Table 5. Structural Equations of Factors Affecting the Effectiveness of Red Flags

\begin{tabular}{|c|c|c|c|c|c|c|}
\hline Sample & Hypothesis & R-Square & $\mathrm{R}_{\text {include }}^{2}$ & $\mathrm{R}_{\text {exclude }}^{2}$ & $\mathrm{f}^{2}$ & Criteria \\
\hline \multirow{6}{*}{ BPKP } & $\operatorname{sex} \rightarrow \mathrm{RF}$ & \multirow{6}{*}{0,894} & \multirow{6}{*}{0,894} & 0,802 & 0,868 & Big \\
\hline & job $\rightarrow R F$ & & & 0,890 & 0,038 & Small \\
\hline & $\mathrm{com} \rightarrow \mathrm{RF}$ & & & 0,759 & 1,274 & Big \\
\hline & $\mathrm{edu} \rightarrow \mathrm{RF}$ & & & 0,839 & 0,519 & Big \\
\hline & $\exp \rightarrow \mathrm{RF}$ & & & 0,886 & 0,075 & Small \\
\hline & $\operatorname{tra} \rightarrow \mathrm{RF}$ & & & 0,789 & 0,991 & Big \\
\hline \multirow{6}{*}{ BPK } & $\operatorname{sex} \rightarrow \mathrm{RF}$ & \multirow{6}{*}{0,828} & \multirow{6}{*}{0,828} & 0,809 & 0,110 & Small \\
\hline & job $\rightarrow R F$ & & & 0,638 & 1,105 & Big \\
\hline & $\mathrm{com} \rightarrow \mathrm{RF}$ & & & 0,823 & 0,029 & Small \\
\hline & edu $\rightarrow$ RF & & & 0,786 & 0,244 & Moderate \\
\hline & $\exp \rightarrow \mathrm{RF}$ & & & 0,828 & 0,000 & Small \\
\hline & $\operatorname{tra} \rightarrow \mathrm{RF}$ & & & 0,755 & 0,424 & Big \\
\hline
\end{tabular}

\subsection{Structural Model}

Through the R-square values were obtained data that shows gender (sex), job position (job), years of service (comp), education (edu), experience (exp), and training (tra) simultaneously had an effect of $89.4 \%$ on effectiveness of red flag (RF) in BPKP. Whereas, in BPK gender (sex), job position (job), years of service (com), education (edu), experience (exp), and training (tra) simultaneously induced an effect of $82.8 \%$ on the effectiveness of red flag (RF). The influence level of each exogenous variable on the red flag effectiveness can be 
obtained from the calculation of the value of $\mathrm{f} 2$ with the following formula (Hair et al., 2014).

Through the $\mathrm{f} 2$ value in table 5 it can be inferred that in BPKP, training (tra) was the variable that had the highest influence on the effectiveness of the red flag, while education (edu) had the least effect. On the other hand, the results in BPK, the years of service (comp) had the highest influence on the effectiveness of the red flag, on the contrary, gender (sex) had the least effect. Furthermore, to prove whether gender, job position, years of service, education, experience, and training had a significant effect on the effectiveness of the red flag, a hypothesis testing which was shown in table 6 was performed.

The results of the first hypothetical testing showed that gender in BPKP influenced the effectiveness of red flags. However, gender in BPK did not affect the effectiveness of red flags. This findings meant that gender or in this case female auditors in BPKP had a higher tendency to use red flags in detecting fraud. This finding was in line with Moyes and Baker [14] which stated that female auditors have a tendency to use red flags in detecting inclination compared to male auditors. The results of this study were also supported by research from Ittonen et al [29] that found female auditors have perseverance, professional skepticism, and a higher level of preparation compared to male. Thus, more audit investment will be generated by female auditors.

On the other hand, gender results in BPK indicated that both male and female sexes, both had the ability to use red flags in detecting fraud. They had the same perception and capability to use red flags in detecting inclination, because it is supported by their level of education, experience and training. The results of this study were supported by Smith et al [8] which stated that gender has no influence on auditor perceptions in using red flags to detect fraud.

The results of the second hypothesis testing showed that job position in BPKP had no effect on the effectiveness of red flags, while job position in BPK influenced red flags effectiveness. Whatever the auditor's position at BPKP tended not to have an effect in using red flags to detect fraud. The results of this study were in line with research by Moyes and Baker [7], which inferred that job position had no influence on the red flags effectiveness in detecting fraud. Whereas, the auditor's job position at the BPK with a higher level of position will tend to have the ability to determine red flags. These results were in accordance with the theory which stated that the position of partner was the most difficult level in the work of an auditor because of his or her great responsibilities, thus, it is required to have adequate knowledge and experience [30]. Hence, someone who was in a higher position had a tendency to use red flags effectively.

The results of the third hypothesis testing demonstrated the years of service at BPKP affect the effectiveness of red flags . On the contrary, the years of service at BPK did not affect the red flags effectiveness. These findings meant that the auditor's longer service period at BPKP could determine the auditor's ability to detect red flags. This finding was supported by studies by Hegazy et al [5] and Moyes [14] namely the work tenure that has been taken by an auditor is capable of detecting fraud. Whereas, the years of service in BPK did not guarantee the ability to determine red flags. This was in line with research from Smith et al [8] which deduced the duration of work has no influence on red flags effectiveness.

The fourth hypothesis testing results showed that education in both BPKP and BPK influenced the effectiveness of red flags. In other words, individuals who had the capacity to change attitudes, ethics, norms or morals of a person or group of people in carrying out their lives properly and help improve the level of thinking towards maturity, would be more able to increase red flags effectiveness compared to individuals who do not carry out the education process. The results of this study were in line with the results of the study by Moyes and Baker $[7,14]$ who stated that having a higher level of education is able to increase the red flags effectiveness in an effort to detect fraud when compared to auditors who don't have a degree. The results of this study are in line with the theory that the level of education of a person influences the mindset in decision making [15,31].

Table 6. Hypothesis Testing Results

\begin{tabular}{ccccccccc}
\hline \multirow{2}{*}{ Information } & \multicolumn{9}{c}{ BPKP } & \multicolumn{3}{c}{ BPK } \\
\cline { 2 - 9 } & Coefficient & $\mathrm{t}_{\text {count it }}{ }^{*}$ & $\mathrm{p}$-value & Ho & Coefficient & $\mathrm{t}_{\text {count it }}{ }^{*}$ & $\mathrm{p}$-value & Ho \\
\hline sex $\rightarrow$ RF & 0,318 & 3,447 & 0,001 & Rejected & 0,150 & 1,211 & 0,226 & Received \\
job $\rightarrow$ RF & 0,071 & 0,630 & 0,529 & Received & 0,529 & 3,978 & 0,000 & Rejected \\
com $\rightarrow$ RF & 0,466 & 4,645 & 0,000 & Rejected & 0,100 & 0,756 & 0,450 & Received \\
edu $\rightarrow$ RF & 0,265 & 2,834 & 0,005 & Rejected & 0,264 & 2,066 & 0,039 & Rejected \\
exp $\rightarrow$ RF & 0,105 & 0,659 & 0,510 & Received & $-0,037$ & 0,181 & 0,856 & Received \\
$\operatorname{tra} \rightarrow \mathrm{RF}$ & 0,379 & 3,293 & 0,001 & Rejected & 0,412 & 2,538 & 0,011 & Rejected \\
\hline
\end{tabular}


The fifth hypothesis testing results proved that experience in both BPKP and BPK had no effect on the effectiveness of red flags. Individuals who have experience or might use red flags in detecting fraud. The findings of the study contradict several studies $[14,15,31,35,36]$ which deduced that an auditor's experience can improve the capability in detecting fraud.

The sixth hypothesis testing results demonstrated that training in BPKP and BPK affected the effectiveness of red flags, which meant that auditors at both BPKP and BPK have the ability to determine red flags in detecting fraud through the training process. They follow training with activities that support their professionalism, thus, they tend to use red flags in detecting fraud better. Therefore, if the auditor had a high level of fraud awareness and knowledge, it would increase the sensitivity to indications of fraud. Thus, the auditor would be better in identifying the effectiveness of red flags to detect fraud. This is in line with research from Moyes, et al. [14], which stated that demographic information in the form of training that supports fraud detection will be able to increase the red flags application in an effort to detect fraud both from the perceptions of external, internal and or government auditors. Moreover, it was also supported by the results of research by Yang et al. [15], that found that the results of fraud training can affect auditor perceptions of the effectiveness of red flags.

\section{Conclusions}

Experience in both BPKP and BPK does not affect the effectiveness of red flags. Individuals who have experience or not will tend to be able to use red flags in detecting fraud. The research findings contradict Meinhardt, et al. [40].

The results of this study have implications for Government Agencies, i.e., BPK and BPKP in that these results can be used as models in anticipating fraud in auditing practices. The results of this research proved that the characteristics of individual auditors in terms of gender, years of service and job position had an influence on the effectiveness of red flags. These findings also provided a sign for BPKP and BPK to put more attention to individual auditors' characteristics when placing forensic auditors in carrying out their work. In addition, the research's result also proved the BPKP and BPK auditors' ability which were shown by education and training had an effect on the effectiveness of red flags. Hence, BPKP and BPK should put more effort into providing their auditors with the opportunity to attend continuous education and training that supports auditors in carrying out their work, especially related to training in the use of IT to detect fraud. For the government, especially the BPK and BPKP, it is recommended to create policies that dictate red flags as a reference for auditors in order to support auditors in detecting fraud.

This study has limitations related to the sensitive nature of ethical research. Respondents might give answers that were not in accordance with what they usually do when conducting audit procedures. Thus, there was a tendency for respondents to consider the conditions as less serious. The sample used in this study is only limited to government auditors. Therefore, the results might not be generalized for private auditors. Future research examining the model as presented in this study could potentially be developed further either by changing the model or the research design using experimental methods. Moreover, it is suggested to consider private auditor (public accountant) as samples, so that the results can be compared with government auditors.

\section{Acknowledgements}

We are very grateful to auditor in government Indonesia for willingness to be respondents in this research.

\section{REFERENCES}

[1] Nwaobia, A. N., Ogundajo, G. O., \& Theogene, N., "Internal audit practices and public financial Management in Rwanda and Nigeria: bridging the Transparency gap in public sector financial Reporting," International Journal of Advanced Academic Research Social Management Sciences, vol. 2, no. 10, pp. 55-77, 2016. https://www.ijaar.org/articles/Volume2-Number10/SocialManagement-Sciences/ijaar-sms-v2n10-oct16-p8.pdf

[2] RI, B., "Ikhtisar Hasil Pemeriksaan (IHPS) II Tahun 2019," Badan Pemeriksa Keuangan, 2019.

[3] Baader, G., \& Krcmar, H. (2018)., "Reducing false positives in fraud detection: Combining the red flag approach with process mining," International Journal of Accounting Information Systems, vol. 31, no. 1, pp. 1-16, 2018. DOI: $10.1016 / j$.accinf.2018.03.004

[4] Moyes, G. D., Young, R., \& Mohamed Din, H. F., 'Malaysian internal and external auditor perceptions of the effectiveness of red flags for detecting fraud," International Journal of Auditing Technology, vol. 1, no. 1, pp. 91-106, 2013. DOI: 10.1504/IJAUDIT.2013.052263

[5] Hegazy, M., \& Kassem, R., "Fraudulent financial reporting: Do red flags really help," Journal of Economics and Engineering, vol. 1, no. 4, pp. 69-79, 2010. http://nectar.northampton.ac.uk/4538/

[6] Shandu, N., "Behavioural Red Flags of Fraud: An Ex Post Assessment of Types and Frequencies," Global Business Review, vol. 2, no. 2, pp. 507-525, 2020. DOI: $10.1177 / 0972150919850410$

[7] Moyes, G. D., \& Baker, C. R., "Factors influencing the use of red flags to detect fraudulent financial reporting," Internal Auditing, vol. 24, no. 3, pp. 33-40, 2009. 
[8] Smith, M., Omar, N. H., Idris, S. I. Z. S., \& Baharuddin, I, "Auditors' perception of fraud risk indicators: Malaysian evidence," Managerial Auditing Journal, vol. 20, no. 1, pp. 73-85, 2005. DOI: 10.1108/02686900510570713

[9] Chung, J., \& Monroe, G., "A research note on the effects of gender and task complexity on an audit judgment," Journal of Behavioral Research in Accounting, vol. 13, no. 1, pp. 111-125, 2001. DOI: 10.2308/bria.2001.13.1.111

[10] Dal Magro, C. B., \& Da Cunha, P. R., "Red flags in detecting credit cooperative fraud: the perceptions of internal auditors," Revista Brasileira de Gestão de Negócios, vol. 19, no. 65, pp. 469-491, 2017. DOI: 10.7819/rbgn.v19i65.2918

[11] Mangala, D., \& Kumari, P., “Auditors' Perception of Red Flag: Indian Evidence. Management Mosaic Traversing Across Assorted Research Arena," India: Wisdom Publication, pp. 1-18, 2016. https://papers.ssrn.com/sol3/p apers.cfm?abstract_id=2739691

[12] Moyes, G. D., "The differences in perceived level of fraud-detecting effectiveness of SAS No. 99 red flags between external and internal auditors," Journal of Business Economics Research, vol. 5, no. 6, pp. 9-26, 2007. DOI: 10.19030/jber.v5i6.2551

[13] Yücel, E., "Effectiveness of Red Flags in Detecting Fraudulent Financial Reporting: An Application In Turkey," Journal of Accounting Finance, vol. 60, no. 1, pp. 139-158, 2013.

http://mufad.org.tr/journal-/attachments/article/716/9.pdf

[14] Moyes, G. D., Din, H. F. M., \& Omar, N. H., "The effectiveness of the auditing standards to detect fraudulent financial reporting activities in financial statement audits in Malaysia," International Business Economics Research Journal, vol. 8, no. 9, pp. 1-17, 2009. DOI: 10.19030/iber.v8i9.3163

[15] Yang, W., Moyes, G. D., Hamedian, H., \& Rahdarian, A, "Professional Demographic Factors That Influence Iranian Auditors Perceptions of The Fraud-Detecting Effectiveness of Red Flags," International Business Economics Research Journal, vol. 9, no. 1, pp. 83-102, 2010. DOI: 10.19030/iber.v9i1.510

[16] Gullkvist, B., \& Jokipii, A., "Perceived importance of red flags across fraud types," Critical Perspectives on Accounting, vol. 24, no. 1, pp. 44-61, 2013. DOI: 10.1016/j.cpa.2012.01.004

[17] Shandu, N, "Behavioural red flags of fraud- A qualitative assessment," Journal of Human Values, vol. 22, no. 3, pp. 221-237, 2016. DOI: 10.1177/0971685816650579

[18] Cressey, D. R., "Other people's money; a study of the social psychology of embezzlement," New Jersey: Patterson Smith Publishing, 1953.

[19] Horwarth, C., "The Mind Behind The Fraudsters Crime: Key Behavioral and Environmental Element", 23rd Annual ACFE Fraud Confrence, USA. 2012.

[20] Mohebi, L., \& Bailey, F., "Exploring Bem's Self Perception Theory in Educational Context," Encyclopaideia, vol. 24, no. 58 , pp. 1-10, 2020. DOI: 10.6092/issn.1825-8670/9891

[21] Singleton, T. W., "Fraud auditing and forensic accounting," Vol. 11, John Wiley \& Sons, 2010, pp. 1-317.
[22] Wolfe, D. T., \& Hermanson, D. R., "The fraud diamond: Considering the four elements of fraud," CPA Journal, vol. 74, no. 12, pp. 38-42, 2004 https://digitalcommons.kennes aw.edu/facpubs/1537

[23] Rustiarini, N. W., Suryandari, N. N. A., \& Nova, I. K. S., "Red flags and fraud prevention on rural banks," Buletin Ekonomi Moneter dan Perbankan, vol. 19, no. 2, pp. 177-206. 2016. DOI: 10.21098/bemp.v19i2.629

[24] Omar, Normah Binti Omar, dan H. F. Mohamad Din., "Fraud Diamond Risk Indicator: An Assessment of Its Importance and Usage," In 2010 International Conference on Science and Social Research (CSSR 2010) (pp. 607-612). IEEE. DOI: 10.1109/CSSR.2010.5773853

[25] Apostolou B, Hassell J, Webber S, dan Sumners G., "The Relative Importance of Management Fraud Risk Factors," Behavioral Research in Accounting, vol. 13, no. 1, pp. 1-24. 2001. DOI: 10.2308/bria.2001.13.1.1.

[26] Robbins, S. P., \& Judge, T., "Essentials of organizational behavior", Pearson Education Inc, 2012

[27] Messier Jr WF, Martinov-Bennie N, dan Eilifsen A. A. "Review and Investigation of Empirical Research on Materiality: Two Decades Later," Auditing: A Journal of Practice \& Theory, vol. 24, no. 2, pp. 153-87. 2005. DOI: 10.2308/aud.2005.24.2.153

[28] Prawansa, K. I., "Gender dalam Perspektif Politik,” Jurnal Panitia Muktamar XXX NU, 1999.

[29] Ittonen, K., Vähämaa, E., \& Vähämaa, S., "Female auditors and accruals quality," Accounting Horizons, vol. 27, no. 2, pp. 205-228, 2013. DOI: $10.2308 /$ acch-50400

[30] IAASB., "International Standard Auditing 220 Quality Control for An Audit of Financial Statement," New York: International Federation of Accountants. 2009.

[31] Hamdan, S. L., Jaffar, N., Ab Razak, R., \& Salleh, N. M. Z. N., "The Effects of Internal Auditor's Competency and Whistleblowing Mechanism on Fraud Detection in Malaysia," International Journal of Applied Business and Economic Research, vol. 15, no. 24, pp. 1-20, 2017. https://www.researchgate.net/profile/Ruzanna_Ab_Razak/ publication/322401872_The_effects_of_internal_auditor

[32] Kuntari, Y., Chariri, A., \& Nurdhiana, N., "The Effect of Auditor Ethics, Auditor Experience, Audit Fees and Auditor Motivation on Audit Quality," Sriwijaya International Journal of Dynamic Economics Business, vol. 1, no. 2, pp. 203-218, 2017. DOI: 10.29259/sijdeb.v1i2.203-218

[33] Cahan, S. F., \& Sun, J., "The effect of audit experience on audit fees and audit quality," Journal of Accounting, Auditing Finance, vol. 30, no. 1, pp. 78-100, 2015. DOI: 10.1177/0148558X14544503

[34] Ocak, M., "The impact of auditor education level on the relationship between auditor busyness and audit quality in Turkey," Cogent Business Management, vol. 5, no. 1, 1517588, 2018. DOI: 10.1080/23311975.2018.1517588

[35] Popoola, O., Che-Ahmad, A., \& Samsudin, R. S., "Forensic accounting knowledge and mindset on task performance fraud risk assessment," International Journal of Business Management, vol. 9, no. 9, pp. 1-16, 2014. DOI: 10.5539/ijbm.v9n9p118 
[36] Rahim, S., Muslim, M., \& Amin, A., "Red Flag And Auditor Experience Toward Criminal Detection Trough Profesional Skepticism,” Jurnal Akuntansi, vol. 23, no. 1, pp. 47-62, 2019. DOI: $10.24912 /$ ja.v23i1.459

[37] Mathis, R. L., \& Jackson, J. H., "Human resource management: Essential perspectives," Cengage Learning, 2011.

[38] Putra, G. S. A., \& Dwirandra, A. A. N. B., "The effect of auditor experience, type of personality and fraud auditing training on auditors ability in fraud detecting with professional skepticism as a mediation variable,"
International research journal of management, IT social sciences, vol. 6 , no. 2, pp. 31-43, 2019. DOI: 10.21744/irjmis.v6n2.604

[39] Hair, J. F., Black, W. C., Babin, B. J., \& Anderson, R. E., "Multivariate data analysis", Pearson new international edition (7ed.). Essex: Pearson Education Limited, 2014.

[40] Meinhardt, J., Moraglio, J. F., \& Steinberg, H. I. (1987). Governmental audits: An action plan for excellence. Journal of Accountancy, vol. 164, no. 1, pp. 86, 1987. https://www.proquest.com/openview/eleb5e85928ebee7f7 388226633 ec504/1.pdf?pq-origsite $=$ gscholar \&cbl $=4$ 